\title{
Venepuncture for calcium assays: should we still avoid the tourniquet?
}

\author{
A.D. McMullan, J. Burns and C.R. Paterson \\ Department of Biochemical Medicine, Ninewells Hospital and Medical School, Dundee DDI 9SY, \\ Scotland, UK.
}

\begin{abstract}
Summary: Blood was collected by venepuncture from nine healthy subjects over a ten minute period before applying a standard tourniquet, and over a ten minute period afterwards. Plasma ionised calcium was unaltered by the tourniquet, whereas total calcium, total protein and albumin in serum increased modestly. However, there was no effect on total calcium adjusted for albumin. Even without albumin adjustment the change in total calcium was negligible within one minute of the application of the tourniquet. We consider that in ordinary clinical practice, there is no need to perform venepuncture for calcium assays without a tourniquet.
\end{abstract}

\section{Introduction}

It has long been recognized that the apparent serum calcium rises if a tourniquet has been applied to distend the veins. This change results from the rise in the concentration of the plasma proteins, to which some $40 \%$ of calcium is bound, as a consequence of the increased ultrafiltration of plasma from capillaries under pressure. Since the reference range for calcium is narrow, small rises may mislead and students are still frequently taught that, for serum calcium assays, a tourniquet should

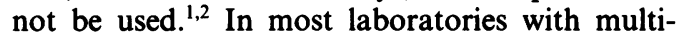
channel analysers, serum calcium values can now be adjusted in the light of simultaneous measurements of the serum albumin.

We wished to examine the continuing validity of the advice that a tourniquet should be avoided for calcium assays.

\section{Subjects and methods}

Nine healthy medical students took part in the study. A Venflon cannula fitted with a two-way valve was inserted into an antecubital vein and kept flushed with isotonic saline. To allow for the effects of posture, each subject remained seated for 10 minutes before any sampling was carried out. In a 10-minute control period blood was taken at the beginning and after 5 and 10 minutes. A standard ward tourniquet was then applied and further

Correspondence: C.R. Paterson, D.M., F.R.C.P. Accepted: 16 February 1990 blood samples were taken after $1,3,5,7$ and 10 minutes.

Total calcium, albumin and total protein were measured by standard methods with a Technicon SMAC (calcium: cresolphthalein complexone; albumin: bromocresol green; total protein: biuret). A Radiometer ICA 1 was used for the simultaneous measurement of plasma ionised calcium and $\mathrm{pH}$. Total serum calcium was 'adjusted' for serum albumin by the formula: adjusted calcium $=$ measured calcium $+0.023[40 \text {-serum albumin }(\mathrm{g} / \mathrm{l})]^{3}$

\section{Results}

Changes in the subjects are shown in the Figure 1. No changes were seen in the initial control period. Application of the tourniquet, even for 10 minutes, led to no change in plasma ionised calcium at pH 7.4 or in 'adjusted' serum calcium. As expected the total serum calcium, unadjusted for albumin, rose during the period in which the tourniquet was applied, but in no subject did the value exceed the upper reference limit. The highest unadjusted serum calcium that was measured after the tourniquet had been in place for 10 minutes was $2.52 \mathrm{mmol} / \mathrm{l}$; the greatest increment seen was $0.19 \mathrm{mmol} / \mathrm{l}$.

\section{Discussion}

Whether the assay of ionised calcium provides an unequivocal 'gold standard' for the assessment of 


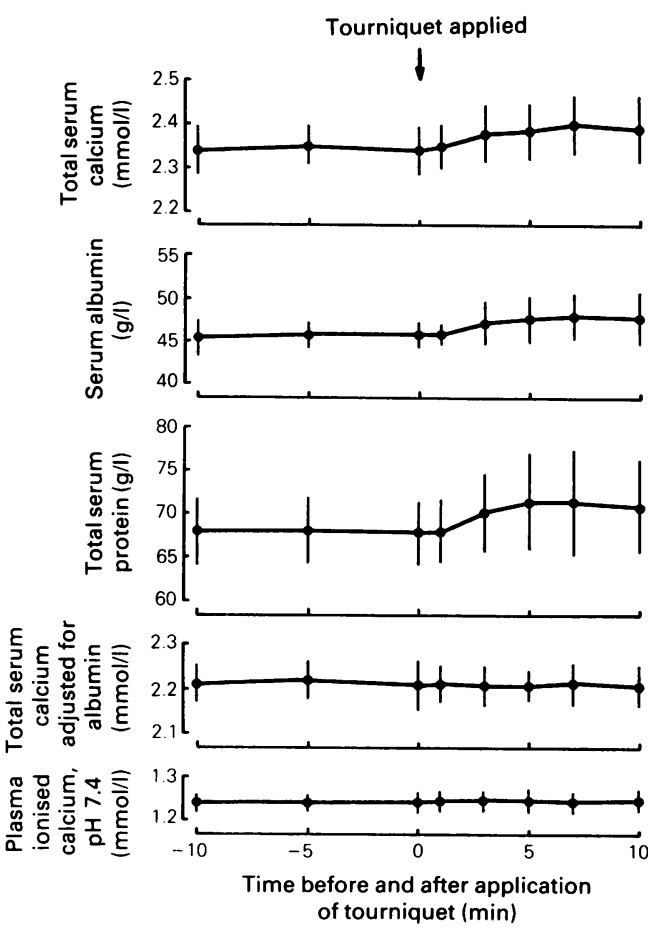

Figure 1 Total serum calcium, serum albumin, total serum protein, total serum calcium adjusted for albumin and plasma ionised calcium concentrations in nine healthy subjects before and after the application of a tourniquet (means and s.d.).

plasma calcium remains controversial. ${ }^{4,5}$ There is a fair measure of agreement that ionised calcium assays have an important place on specific occasions, such as in patients undergoing liver

\section{References}

1. Hope, R.A. \& Longmore, J.M. Oxford Handbook of Clinical Medicine. Oxford University Press, Oxford, 1985, p. 572.

2. Zilva, J.F., Pannall, P.R. \& Mayne, P.D. Clinical Chemistry in Diagnosis and Treatment. Edward Arnold, London, 1988, p. 447.

3. Butler, S.J., Payne, R.B., Gunn, I.R., Burns, J. \& Paterson, C.R. Correlation between serum ionised calcium and serum albumin concentrations in two hospital populations. Br Med J 1984, 289: $948-950$.

4. Kanis, J.A. \& Yates, A.J.P. Measuring serum calcium. Br Med $J$ 1985, 290: 728-729.

5. Payne, R.B. Correcting total serum calcium. Lancet 1989, i: 562. transplantation and in patients with multiple myeloma in some of whom the paraprotein binds calcium. ${ }^{6}$ However good the clinical case for its provision, and despite improvement in the instrumentation, ${ }^{7}$ this assay is not widely available in the United Kingdom. At present therefore, though not ideal, albumin-adjusted calcium is used and should be used for most patients. ${ }^{8}$

We are aware of the limitations of 'albuminadjusted' calcium. The correction factor and reference range for this measurement depend on the analytical methods for both calcium and albumin and should be determined for each laboratory as should the range of serum albumin concentrations over which the factor can be applied. The relationship between total calcium and albumin in serum may differ at albumin levels below $30 \mathrm{~g} / 1$ when albumin is measured by a bromocresol green technique. ${ }^{9}$ For this reason the procedure for albumin correction may not be completely accurate in sick patients with very low serum albumin levels.

Nevertheless in our study no change in albuminadjusted calcium was seen after a tourniquet had been in place for as long as 10 minutes. Even with unadjusted total calcium figures the rise was minimal unless the tourniquet application was prolonged. In routine clinical practice the tournie quet is generally in place for a very short time. Wo consider that the still current advice to avoid tourniquet in venepuncture for calcium assays is inappropriate.

\section{Acknowledgements}

We thank Dr B. Lipworth for his help and the Scottish Home and Health Department for the provision of the ionised calcium analyser.

6. Gray, T.A. \& Paterson, C.R. The clinical value of ionised calcium assays. Ann Clin Biochem 1988, 25: 210-219.

7. Buckley, B.N. \& Russell, I.J. The measurement of ionised calcium in blood plasma. Ann Clin Biochem 1988, 25: 447-465.

8. Iqbal, S.J., Giles, M., Ledger, S., Nanji, N. \& Howl, T. Need for albumin adjustments of urgent total serum calcium. Lancet 1988, ii: $1477-1478$.

9. Ashby, J.P., Wright, D.J. \& Rinsler, M.G. The adjusted serum calcium concept - a reappraisal. Ann Clin Biochem 1986, 23: $533-537$. 